All letters must be typed with double spacing and signed by all authors.

No letter should be more than 400 words.

For letters on scientific subjects we normally reserve our correspondence columns for those relating to issues discussed recently (within six weeks) in the BMF.

We do not routinely acknowledge letters. Please send a stamped addressed envelope if you would like an acknowledgment.

Because we receive many more letters than we can publish we may shorten those we do print, particularly when we receive several on the same subject.

\section{Sudden infant death syndrome}

SIR, - The editorial by Professor A D Milner and Dr N Ruggins ${ }^{1}$ and the paper by Professor G A de Jonge and colleagues ${ }^{2}$ present increasing evidence that infants who sleep prone are at greater risk of the sudden infant death syndrome.

It will undoubtedly be possible to make post hoc modifications to theories of causation of the sudden infant death syndrome to accommodate this observation, but only one hypothesis predicts it a priori. This is the idea that the syndrome is caused by toxins produced by common bacteria growing in the nasopharynx after a viral infection. This explains the key epidemiological features of the syndrome including seasonality, association with viral infection, age distribution, association with sleep, and excess incidence at weekends. ${ }^{4}$ Association with sleep and the excess incidence are thought to be caused by pooling of upper respiratory tract secretions during sleep, which is exacerbated at weekends when infants are left for longer periods in their cots. Pooling of these secretions will increase if the infant sleeps face down as this raises the drainage outlet through the nasopharynx above that of the upper respiratory passages. This factor will become more important if ciliary action is also impaired by a preceding viral infection.

There is evidence of bacterial overgrowth in the nasopharynx in infants who succumb to the sudden infant death syndrome, ${ }^{5}$ and the bacterial isolates produce lethal toxins in experimental models. ${ }^{67}$ Thus research should be focused not just on the respiratory tract, as suggested by Professor Milner and Dr Ruggins, but more finely on respiratory tract bacterial toxins.

JAMES A MORRIS Department of Microbiology, Histology, and Cytology, Lancaster Moor Hospital,

Lancaster LAl 3JR

1 Milner AD, Ruggins N. Sudden infant death syndrome. BrMed f 1989;298:689-90. (18 March.)

2 de Jonge GA, Engelberts AC, Koomen-Liefting AJM, Kostense PJ. Cot death and prone sleeping position in The Netherlands. $\operatorname{BrMed~f~1989;298:722.~(18~March.)~}$

3 Morris JA, Haran D, Smith A. Hypothesis: common bacterial toxins are a possible cause of the sudden infant death syndrome. Med Hypotheses 1987;22:211-22.

4 Morris JA. Increased risk of sudden infant death syndrome in older infants at weekends. Br Med f 1986;293:566.

5 Telford DR, Morris JA, Hughes P, et al. The nasopharyngeal bacterial flora in the sudden infant death syndrome. $\mathcal{I}$ Infect (in press).

6 Lee S, Barson AJ, Drucker DB, Morris JA, Telford DR. Lethal challenge of gnotobiotic weanling rats with bacterial isolates from cases of sudden infant death syndrome (SIDS). $\mathcal{J}$ Clin Pathol 1987;40:1393-6.

7 Lee S, Barson AJ, Drucker DB, Morris JA, Telford DR. Lethal toxins from cot death (SIDS) bacterial isolates - a detection system using embryonated eggs. F Med Microbiol 1988;25:xvi.

SIR,-Dr Alice M Stewart's letter' is a reminder of the marked seasonality in deaths from leukaemia during 1953-70 among infants aged under 6 months, ${ }^{2}$ with $70 \%$ of deaths occurring in those born during the first half of the year.

The National Registry of Childhood Tumours routinely receives notifications of leukaemia in children from cancer registrations, death certificates, the Medical Research Council leukaemia trials, and the United Kingdom Children's Cancer Study Group. The table shows all cases of leukaemia in Britain notified to the registry among infants born during 1971-86. Overall, $41 \%$ of the children had birth dates in January to June and 59\% in July to December. The proportion of cases after July to December births was highest for acute lymphoblastic leukaemia $(62 \%)$ and for children whose leukaemia was diagnosed at ages from 6 to 11 months $(64 \%)$. The ratio of births in the first half of the year to those in the second half did not differ appreciably between 1971 and 1978 and between 1979 and 1986, though for 1984-6 only $52 \%$ of leukaemias followed July to December births. The excess of births in the second half of the year among children aged 6 to 11 months suggested that the distribution of birth months for children diagnosed during the second year of life should also be examined. Among the 542 children born during 1971-85 (ascertainment is clearly still incomplete for 1986 births) with leukaemia diagnosed at age 1 year, only a slight excess $(53 \%)$ were born in July to December.

The seasonal bias in birth date of infants with leukaemia thus moved from the first half to the second half of the year between the 1960s and 1970 s, before becoming less marked in the mid1980 s. If the seasonality of leukaemia in infants is to be explained by some competing cause of death the search must be for a cause whose seasonality has also shifted. A similarly changing seasonality would also be required in any factor which might protect against leukaemia. Two studies have shown an increased risk of leukaemia in childhood with failure to receive the standard childhood immunisations, ${ }^{34}$ though the evidence of a direct role of infections in infancy in the aetiology of leukaemia is inconclusive. ${ }^{+5}$ Infections may seem plausible seasonal factors implicated in leukaemia in infancy, but it is not clear whether there are any that have displayed such a clear change in seasonality as the incidence of leukaemia in very young children. The sudden infant death syndrome had seasonality of month of birth complementary to that of infant leukaemia during $1953-70,{ }^{2}$ but a subsequent reversal in the seasonal pattern of cot deaths has not been reported.

C A STILLER

Childhood Cancer Research Group,

Radcliffe Infirmary,

Oxford OX26HE

1 Stewart AM. Sudden infant death svndrome: faulty maturation of haemoglobin and immunoglobulins. Br Med $\mathcal{F}$ 1989;298: $521-2$.

2 Stewart A. Infant leukaemias and cot deaths. Br Med $\mathcal{F}$ 1975;ii: 605-7.

3 Kneale GW, Stewart AM, Kinnier Wilson LM. Immunization against infectious diseases and childhood cancers. Cancer against infectious diseases and child

4 McKinney PA, Cartwright RA, Saiu JMT, et al. The interregional epidemiological study of childhood cancer (IRESCC) a case control study of aetiological factors in leukaemia an lymphoma. Arch Dis Child 1987;62:279-87.

Van Steensel-Moll HA, Valkenburg HA, Van Zanen GE. Childhood leukaemia and infectious diseases in the first year of life: a register-based case-control study. Am f E Eidemio 1986;124:590-4.

Numbers of cases of leukaemia in infants aged $<1$ year born between 1971 and 1986 in Britain (from National Registry of Childhood Tumours)

\begin{tabular}{|c|c|c|c|c|c|}
\hline \multirow{3}{*}{$\begin{array}{l}\text { Age at diagnosis } \\
\text { (months) }\end{array}$} & \multirow[b]{3}{*}{ Type of leukaemia } & \multicolumn{4}{|c|}{ Year of birth } \\
\hline & & \multicolumn{2}{|c|}{ 1971-8 } & \multicolumn{2}{|c|}{$1979-86$} \\
\hline & & January-June & July-December & January-June & July-December \\
\hline \multirow{4}{*}{$0-5$} & Acute lymphoblastic & 17 & 27 & 21 & 26 \\
\hline & Acute non-lymphoblastic & 15 & 16 & 15 & 13 \\
\hline & Other and unspecified & 8 & 12 & 8 & 7 \\
\hline & Total & 40 & 55 & 44 & 46 \\
\hline \multirow{4}{*}{$6-11$} & Acute lymphoblastic & 13 & 25 & 13 & 25 \\
\hline & Acute non-lymphoblastic & 9 & 16 & 8 & 15 \\
\hline & Other and unspecified & 6 & 8 & 4 & 4 \\
\hline & Total & 28 & 49 & 25 & 44 \\
\hline \multirow{4}{*}{ Total $0-11$} & Acute lymphoblastic & 30 & 52 & 34 & 51 \\
\hline & Acute non-lymphoblastic & 24 & 32 & 23 & 28 \\
\hline & Other and unspecified & 14 & 20 & 12 & 11 \\
\hline & Total & 68 & 104 & 69 & 90 \\
\hline \multicolumn{2}{|c|}{ Rate per $10^{\prime}$ live births } & $2 \cdot 32$ & $3 \cdot 70$ & $2 \cdot 44$ & $3 \cdot 16$ \\
\hline
\end{tabular}

